
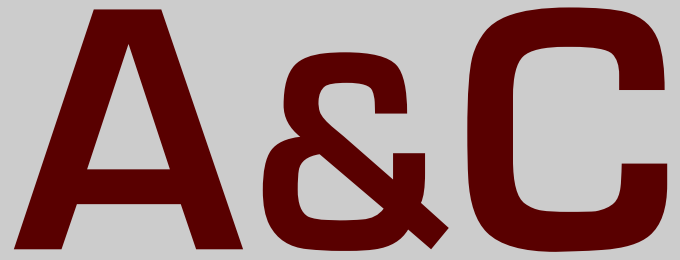

\title{
REVISTA DE DIREITO
} ADMINISTRATIVO \& CONSTITUCIONAL

Angela Cassia Costaldello - Augusto Durán Martínez - Carlos E. Delpiazzo • Celso Antônio Bandeira de Mello - Clèmerson Merlin Clève - Jaime Rodríguez-Arana

- Javier Parquet Villagra • José Luis Meilán Gil • Juan Carlos Cassagne • Juarez Freitas - Pablo Angel Gutiérrez Colantuono - Paulo Roberto Ferreira Motta - Regina Maria Macedo Nery Ferrari • Romeu Felipe Bacellar Filho • Valmir Pontes Filho
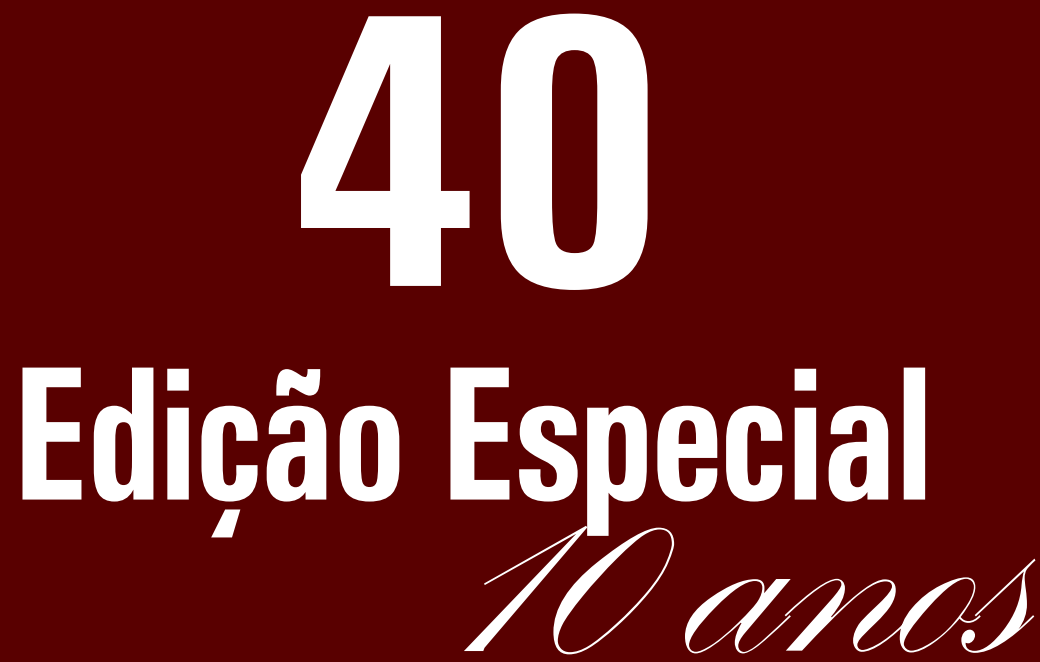

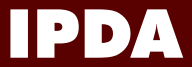

Editora Fórum
INSTITUTO DE DIREITO ROMEU FELIPE Instituto Paranaense de Direito Administrativo 


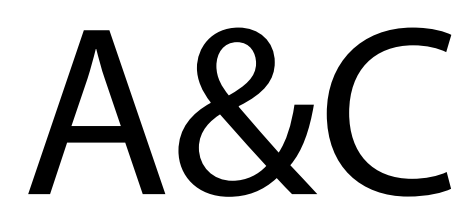

Revista de Direito Administrativo \& Constitucional

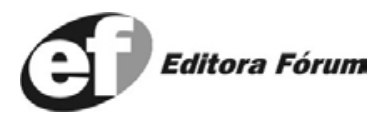

ISSN 1516-3210 


\title{
A\&C REVISTA DE DIREITO ADMINISTRATIVO \& CONSTITUCIONAL
}

\author{
IPDA \\ Instituto Paranaense \\ de Direito Administrativo
}

INSTITUTO DE DIREITO

ROMEU FELIPE

BACELLAR

(c) 2010 Editora Fórum Ltda.

Todos os direitos reservados. É proibida a reprodução total ou parcial, de qualquer forma ou por qualquer meio eletrônico ou mecânico, inclusive por meio de processos xerográficos, de fotocópias ou de gravação, sem permissão por escrito do possuidor dos direitos de cópias (Lei n 9.610, de 19.02.1998).

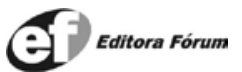

Luís Cláudio Rodrigues Ferreira Presidente e Editor
Coordenação editorial: Olga M. A. Sousa

Revisoras: Lourdes Nascimento, Ana Flávia Inácio Ferreira

Projeto gráfico e diagramação: Luiz Alberto Pimenta

Bibliotecário: Ricardo José dos Santos Neto - CRB 2752 - 6a Região

Os conceitos e opiniões expressas nos trabalhos assinados são de responsabilidade exclusiva de seus autores.

Impressa no Brasil / Printed in Brazil

Distribuída em todo o Território Nacional

Av. Afonso Pena, 2770 - 15\%/16 andares - Funcionários CEP 30130-007 - Belo Horizonte/MG - Brasil Tel.: 08007043737

Internet: www.editoraforum.com.br e-mail: editoraforum@editoraforum.com.br

A246 A\&C Revista de Direito Administrativo \& Constitucional.
ano 3, n. 11, jan./mar. 2003. Belo Horizonte: Fórum, 2003.
Trimestral
ano 1, n. 1, 1999 até ano 2, n. 10, 2002 publicada pela
Editora Juruá em Curitiba
ISSN 1516-3210
1. Direito Administrativo. 2. Direito Constitucional. I. Fórum.
CDD: $342 \quad$ CDU: 33.342

Revista do Programa de Pós-graduação do Instituto de Direito Romeu Felipe Bacellar (Instituição de Pesquisa especialmente credenciada pelo Ministério da Educação - Portaria ${ }^{\circ}$ 2.012/06), em convênio com o Instituto Paranaense de Direito Administrativo (entidade associativa de âmbito regional filiada ao Instituto Brasileiro de Direito Administrativo).

A linha editorial da A\&C - Revista de Direito Administrativo \& Constitucional segue as diretrizes do Programa de Pós-Graduação do Instituto de Direito Romeu Felipe Bacellar em convênio com o Instituto Paranaense de Direito Administrativo. Procura divulgar as pesquisas desenvolvidas na área de Direito Constitucional e de Direito Administrativo, com foco na questão da efetividade dos seus institutos não só no Brasil como no direito comparado, com ênfase na questão da interação e efetividade dos seus institutos, notadamente América Latina e países europeus de cultura latina.

A publicação é decidida com base em pareceres, respeitando-se o anonimato tanto do autor quanto dos pareceristas (sistema double-blind peer review).

Desde o primeiro número da Revista, $75 \%$ dos artigos publicados (por volume anual) são de autores vinculados a pelo menos cinco instituições distintas do Instituto de Direito Romeu Felipe Bacellar.

A partir do volume referente ao ano de 2008, pelo menos $15 \%$ dos artigos publicados são de autores filiados a instituições estrangeiras.

Esta revista está indexada em:

- Base RVBI (Catálogo do Senado)

- Library of Congress (Biblioteca do Senado dos EUA)

- Ulrich's Periodicals Directory

A\&C - Revista de Direito Administrativo \& Constitucional realiza permuta com as seguintes publicações:

- Revista da Faculdade de Direito, Universidade de São Paulo (USP), ISSN 0303-9838

- Rivista Diritto Pubblico Comparato ed Europeo, ISBN/EAN 978-88-348-9934-2 
Diretor-Geral

Romeu Felipe Bacellar Filho

Diretor Editorial

Paulo Roberto Ferreira Motta

Editora Acadêmica Responsáve Ana Cláudia Finger

Secretário Editorial Executivo

Daniel Wunder Hachem

Conselho Diretivo

Adriana da Costa Ricardo Schier

Edgar Chiuratto Guimarães

Célio Heitor Guimarães

Conselho Editorial

Adilson Abreu Dallari (PUC/SP)

Alice Gonzalez Borges (UFBA)

Carlos Ari Sundfeld (PUC/SP)

Carlos Ayres Britto (UFSE)

Carlos Delpiazzo (Universidad de La República - Uruguai)

Cármen Lúcia Antunes Rocha (PUC/MG)

Celso Antônio Bandeira de Mello (PUC/SP)

Clèmerson Merlin Clève (UFPR)

Clovis Beznos (PUC/SP)

Enrique Silva Cimma (Universidade do Chile)

Eros Roberto Grau (USP)

Guillermo Andrés Muñoz (in memoriam)

Jaime Rodríguez-Arana Muñoz (Universidad de La Coruña - Espanha)

Jorge Luís Salomoni (in memoriam)

José Carlos Abraão (UEL)

José Eduardo Martins Cardoso (PUC/SP)

José Luís Said (UBA - Argentina)

José Mario Serrate Paz (Universidade de Santa Cruz - Bolívia)

Juan Pablo Cajarville Peluffo (Universidad de La República - Uruguai) Juarez Freitas (UFRGS)

Julio Rodolfo Comadira (in memoriam)

Lúcia Valle Figueiredo (in memoriam)

Luís Enrique Chase Plate (Universidade Nacional do Paraguai)

Manoel de Oliveira Franco Sobrinho (in memoriam)

Marçal Justen Filho (UFPR)

Marcelo Figueiredo (PUC/SP)

Márcio Cammarosano (PUC/SP)

Maria Cristina Cesar de Oliveira (UFPA)

Nelson Figueiredo (UFG)

Odilon Borges Junior (UFES)

Pascual Caiella (Universidad de La Plata - Argentina)

Paulo Eduardo Garrido Modesto (UFBA)

Paulo Henrique Blasi (UFSC)

Paulo Neves de Carvalho (in memoriam)

Pedro Paulo de Almeida Dutra (UFMG)

Regina Maria Macedo Nery Ferrari (UFPR)

Rogério Gesta Leal (UNISC)

Rolando Pantoja Bauzá (Universidade Nacional do Chile) Sérgio Ferraz (PUC/RJ)

Valmir Pontes Filho (UFCE)

Weida Zancaner (PUC/SP)

Yara Stroppa (PUC/SP)

Conselho Consultivo

Prof. Dr. Antonello Tarzia (Università Commerciale Luigi Bocconi - Itália)

Profa. Dra. Cristiana Fortini (UFMG - MG)

Prof. Dr. Eduardo Biacchi Gomes (UniBrasil - PR)

Prof. Dr. Eduardo Talamini (UFPR - PR)

Prof. Dr. Emerson Gabardo (PUC/PR)

Prof. Dr. Fabrício Macedo Motta (UFG - GO)

Prof. Dr. Fernando Vernalha Guimarães (UniCuritiba - PR)

Prof. Dr. Gustavo Henrique Justino de Oliveira (USP - SP)

Prof. Dr. Isaac Damsky (Universidad de Buenos Aires - Argentina)

Prof. Dr. José Pernas García (Universidad de La Coruña - Espanha)

Prof. Dr. Mário Aroso de Almeida (Universidade Católica de Lisboa - Portugal)

Prof. Dr. Paulo Ricardo Schier (UniBrasil - PR)

Prof. Dr. Paulo Roberto Ferreira Motta (UTP - PR)

Profa. Dra. Raquel Dias da Silveira (Faculdades Dom Bosco - PR)

Profa. Dra. Tatyana Scheila Friedrich (UFPR - PR)

Prof. Dr. Ubirajara Costódio Filho (UniCuritiba - PR)

Profa. Dra. Vanice Lírio do Valle (Universidade Estácio de Sá - RJ) 


\section{Intereses generales e interés público desde la perspectiva del derecho público español}

José Luis Meilán Gil

Catedrático de Derecho Administrativo - Universidad de La Coruña. Ex-Consejero de Estado.

Resumen: El tema ocupa un lugar central en el derecho administrativo y es objeto de diferente entendimiento en la historia de los distintos ordenamientos jurídicos, con nuevas facetas en cada una de sus etapas. Tomando como referencia el Derecho español, una rápida ojeada a la vigente Constitución de 1978 permite comprobar variadas referencias a expresiones como "interés general", "intereses generales", "interés nacional", "interés público". Lo que procede y se pretende en esta aproximación es llevar a cabo un acotamiento de esos conceptos lábiles utilizando la técnica del contraste, en la convicción de que el interés general o el interés público no pueden usarse como cobertura indiscriminada del poder público, que los debe tener por criterio de actuación, que los ha de garantizar y a los que debe servir. En definitiva ni el titular del poder -Gobierno o Administración- deben apropiarse del interés general o el interés público, como si fueran domini de ellos, ni pueden desentenderse a favor del interés privado, abdicando ilegítimamente de su función.

Palabras clave: Intereses generales. Interés público. Derecho Público Español.

Sumario: I Planteamiento - II Intereses generales en la organización política de la sociedad - III Administración Pública, intereses generales e interés público - 1 Etapa predemocrática - 2 El paradigma constitucional - 2.1 La Administración Pública como servidora de los intereses generales - 2.2 Los derechos fundamentales son el núcleo irreductible de los intereses generales - 2.3 Intereses generales como parámetro de la estructura del Estado autonómico - 2.4 La determinación del interés general - IV Interés general y conformidad a derecho de la actuación de la administración V Intereses generales e interés público en la suspensión y revocación de actos administrativos - 1 Intereses generales e intereses privados - 2 Conflicto de intereses públicos - $3 \mathrm{El}$ interés público como límite de la revocación VI La permanencia del interés público - VII A modo de conclusiones

\section{Planteamiento}

El tema ocupa un lugar central en el derecho administrativo y es objeto de diferente entendimiento en la historia de los distintos ordenamientos jurídicos, con nuevas facetas en cada una de sus etapas. Tiene que ver con el fin que justifica la organización política de la convivencia, llámese civitas o Estado o Humanidad como ahora empieza a denominarse 
de la mano de la globalización. Ha de abordarse con esa amplia visión porque tengo la convicción arraigada de que el Derecho ha de ser entendido como un fenómeno cultural, sin cuya perspectiva me parece difícil comprender instituciones y categorías del Derecho administrativo, que prefiero integrarlo en la más amplia expresión de Derecho Público.'

Tomando como referencia el Derecho español, una rápida ojeada a la vigente Constitución de 1978 permite comprobar variadas referencias. Se habla de intereses generales en relación con la Administración Pública (art. 103). De interés nacional y de interés general en relación con la estructura y funcionamiento del Estado compuesto que es el autonómico (art. 144 y arts. 150 y 155) y en ese sentido para delimitar competencias del Estado y de las Comunidades autónomas, por ejemplo en materia de puertos y aeropuertos (art. 149, 1, 20) u obras públicas (art. 149, 1, 24). Al interés general esta subordinada toda la riqueza del país (art. 128, 1) o por exigencias de ese interés puede acordarse por ley la intervención de empresas, además de reservar al sector público recursos o servicios esenciales (art. 128, 2). Para el cumplimiento de fines de interés general podrá establecerse un servicio civil.

Dentro del capítulo dedicado a los principios rectores de la política social y económica, que "informarán la legislación positiva, la práctica judicial y la actuación de los poderes públicos" (art. 53, 3) se dice que estos últimos "promoverán la ciencia y la investigación científica y técnica en beneficio del interés general" (art. 44, 2) y que regularán "la utilización del suelo de acuerdo con el interés general para evitar la especulación" (art. 47).

Al tratar del Ministerio Fiscal, la Constitución señala por misión, entre otras, promover la justicia en defensa de la legalidad, de los derechos de los ciudadanos y del interés público tutelado por la ley (art. 124, 1). La legislación general y sectorial ofrece un muestrario suficiente. En la ley de la jurisdicción contencioso-administrativa de 13 de julio de 1998 (en adelante LJCA) se prevé que el juez o Tribunal podrá denegar la medida cautelar cuando de ésta pudiera seguirse perturbación grave de los intereses generales (art. 130, 2). El recurso de casación en interés

\footnotetext{
Una muestra de esa convicción en MEILÁN GIL, J. L. La cláusula de progreso en los servicios públicos, IEA, Madrid, 1968, con prólogo de J. L. VILLAR PALASÍ y reiterada en Progreso tecnológico y servicios públicos, Thomson-Civitas, Cizur Menor, 2006 y en la orientación metodológica concretada en el Derecho administrativo constitucional aceptada y difundida por mi discípulo J. RODRÍGUEZ-ARANA, Derecho administrativo español, t. I, Introducción al Derecho administrativo constitucional, Netbiblo, A Coruña, 2008.
} 
de la ley podrá interponerse contra determinadas sentencias cuando los legitimados para ello "estimen gravemente dañosa para el interés general y errónea la resolución dictada" (art. 100).

La Administración autora de un acto que pretenda su anulación judicial debe previamente declararlo lesivo para el interés público (arts. 43; 19,$2 ; 45,4$ LJCA) tratándose de actos favorables para los interesados y que sean anulables (art. 103 de la Ley 30/1992 de 26 de noviembre de Régimen jurídico de las Administraciones Públicas y Procedimiento administrativo común, en adelante LRJAPAC). Así mismo el interés público impide la revocación por la Administración de sus actos de gravamen o desfavorables (art. 105 LRJAPAC). El derecho de acceso a archivos y registros puede ser denegado "cuando prevalezcan razones de interés público" (art. 37, 4 LRJAPAC).

En la Ley 30/2007 de 30 de octubre de contratos del sector público (en adelante LCSP) se prevé la modificación de los contratos "por razones de interés público debidamente justificado".2

En casos de incompatibilidad de aprovechamientos mineros, Gobierno o Administración determinará los que sean de mayor interés o utilidad pública. ${ }^{3} \mathrm{Si}$ a lo que acaba de exponerse se añaden preceptos que implícitamente se refieren al interés público y que tanto en la Constitución como en la legislación ordinaria se habla de otros intereses - propios de Comunidades autónomas y entidades locales (art. $137 \mathrm{CE}$ ), intereses económicos y sociales propios de sindicatos y asociaciones empresariales (art. $7 \mathrm{CE}$ ), intereses económicos propios de las organizaciones profesionales (art. $52 \mathrm{CE}$ ) - se llega con facilidad a la comprobación de la complejidad del tema que subyace en expresiones tan plausibles como el interés general o interés público.

Cuestiones a plantear es si nos encontramos ante expresiones multívocas o equivalentes, y en relación con ello cual sería su contenido y quién lo determina, si es posible definirlo. Con agudeza y simpatía Guillermo Andrés Muñoz, comparó en ese sentido el interés público al amor: es más fácil sentirlo que definirlo. ${ }^{4}$

El problema se complica cuando quiere hacerse del interés público la noción clave del Derecho administrativo, a lo que ha sido inclinada la

\footnotetext{
Arts. $202 ; 232 ; 245, \mathrm{~g} ; 258$ y $272 ; 282$.

Art. 36 de la Ley 22/1973 de 21 de julio; art. 8 de la ley 54/1980 de 5 de noviembre.

4 "El interés público como el amor", Conferencia inaugural en el V Congreso de Derecho Público del MERCOSUR, 28 de mayo de 2003. En la misma dirección, referido a España, NIETO, A. El desgobierno de lo público, Ariel, 2008, pp. 232-234.
} 
doctrina administrativa francesa para resolver el problema que plantea la dualidad de competencias de su peculiar organización jurisdiccional, ${ }^{5}$ que he juzgado un desenfoque metodológico producido por un mimetismo injustificado cuando la necesidad de elegir el juez competente es más imaginaria que real. ${ }^{6}$

Lo que procede y se pretende en esta aproximación es llevar a cabo un acotamiento de esos conceptos lábiles utilizando la técnica del contraste - a qué se oponen en cada caso - en la convicción de que el interés general o el interés público no pueden usarse como cobertura indiscriminada del poder público, que los debe tener por criterio de actuación, que los ha de garantizar y a los que debe servir.

Esas expresiones contienen una innegable fuerza ideológica para la legitimación del poder. Su uso espurio ${ }^{7}$ no impide reconocer que existe algo común en su apreciación que justifica de un modo legítimo el ejercicio del poder, necesario para una organización razonable de la vida en sociedad.

En definitiva ni el titular del poder - Gobierno o Administración - deben apropiarse del interés general o el interés público, como si fueran domini de ellos, ni pueden desentenderse a favor del interés privado, abdicando ilegítimamente de su función. Esto es lo que orienta las reflexiones que siguen.

\section{Intereses generales en la organización política de la sociedad}

La justificación del poder público se ha formulado de varias maneras y con diferentes nombres a lo largo de la historia, a la que va asociada una larga lista de ilustres pensadores, de cita innecesaria. Tiene que ver con los fines que se propone la organización política. Dicho de una manera rápida, con técnica pictórica impresionista, el ejercicio del poder público se justifica por y para la procura del bien común, el vivere bene de los miembros de la sociedad política en expresiones clásicas de

\footnotetext{
Primera sería la puissance publique (HAURIOU), contra lo que se alza la idea del service public (DUGUIT), se intenta sustituir por "I'interêt general" (WALLINE), la combinación de puissance publique y pouvoir executif (VEDEL) para concluir que no es necesario acudir a una noción única, poniendo el acento en la existencia de prerrogativas de la Administración sin equivalente en las relaciones entre particulares (Cfr. RIVERO, J. WALINE, J., Droit administratif, 15a ed., Dalloz, París, 1994, pp. 26-30).

6 MEILÁN GIL, J. L., El proceso de la definición del Derecho administrativo, ENAP, Madrid, 1967, pp. 39-40, con cita de WOLF que explica el fracaso del intento de querer encontrar una noción única de Administración,

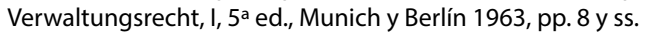

7 NIETO, A., El desgobierno... pp. 233 es hipercrítico. La apelación a los intereses generales es "retórica constitucional", "refinada hipocresía" del dominador para imponer su voluntad y obtener provecho en beneficio de su persona, su grupo o su clase.
} 
Aristóteles y Tomás de Aquino, ${ }^{8}$ la felicidad de los súbditos y el bienestar en la época y la ilustración y el despotismo ilustrado, ${ }^{9}$ el reconocimiento de derechos individuales de los ciudadanos en la onda de la Revolución francesa y la conservación del orden público en la Concepción liberalburguesa, en garantizar los derechos fundamentales de la persona, servicios esenciales y la calidad de vida en el constitucionalismo contemporáneo. No importa ahora insistir en la disociación palmaria entre postulados y realidad, sino en subrayar que, de una u otra manera, con mayor o menor profundidad, esas formulaciones encuentran su razón de ser en las personas que constituyen una comunidad.

Recorriendo río arriba la historia podría decirse con palabras clásicas que ese vivir bien, virtuosamente, felizmente, de cada individuo humano es un "vivir bien junto a otros" (Aquino) ${ }^{10}$ porque "el hombre feliz tiene necesidad de amigos... para beneficiarlos... y también para ser por ellos ayudado" (Aristóteles). El interés particular cede ante el de todos, que no se identifica con el del titular del Poder. Y esto vale también y con mayor razón si cabe para las organizaciones de carácter global cuya actuación sobrepasa los Estados. El interés global se corresponde con el de la Humanidad." Se trata de hacer reales "los derechos iguales e inalienables de todos los miembros de la familia humana",12 sostenible con relación a futuras generaciones.

Conviene recordar estas ideas porque en el curso de la historia y en concreto del Derecho público se han difuminado o su apelación ha supuesto concretas y reprobables manifestaciones de corrupción del Derecho. La "razón de Estado" como guía del príncipe virtuoso, que en la obra de Maquiavelo justifica la adopción de medidas excepcionales para conservar o incrementar la salud y la fuerza del Estado, ofrece muestras de su torcida aplicación en el Antiguo Régimen.

En el Staasrecht, ${ }^{13}$ con su fundamento en la filosofía idealista según la cual el Estado desarrolla dialécticamente la justicia y encarna

8 Cfr. S. Thomae Aquinitatis, Inm decem libros Aristotelis ad Nicomachum expositio, Marietti, 1964, I lectio I, 4; y In octo libros Politicorum Aristotelis expositio, Marietti, 1996, I lectio, 11 y 31.

9 Cfr. NIETO, A, "Algunas precisiones sobre el concepto de policía", RAP, n. 81, (1976), pp. 45-47; GALLEGO ANABITARTE, A., Poder y Derecho, Marcial Pons, 2009.

${ }_{10} \mathrm{Cfr}$. In decem... t. 1, 4 "et sic homini auxiliatior multitudo civilis, ipse est pars, non solum quantum ad corporalia".

11 Cfr. MEILÁN GIL, J. L. "Global Administrative Law and Human Rights", "Fundamento principial del Derecho administrativo global", Libro homenaje al profesor Mariano Baena del Alcázar (en prensa).

12 Algo muy distinto al sacrificio de una generación según praxis marxista.

13 Sobre un supuesto inicial carácter "milenarista" de la expresión, cfr. GALLEGO ANABITARTE, A, Poder... pp. 353. 
el ideal ético, ${ }^{14}$ llegó a afirmarse que el "Poder va por delante del Derecho" y esa raíz explica que se llegara al "Führer Prinzip" con el nacionalsocialismo.

Los Estados totalitarios se han asentado en la sacralidad del Estado. El "interés general" ha sido manipulado en la dictaduras, bajo su consideración de "seguridad nacional" con distintas manifestaciones, para justificar la minoración de derechos fundamentales y libertades públicas. La apelación al orden público es paradigmática. ${ }^{15}$

Las inmunidades del Poder son otras muestras. Ha ocurrido con el nacimiento ${ }^{16}$ y utilización abusiva del "acto político"17 o los actos discrecionales de la Administración Pública. ${ }^{18}$ En definitiva se trataba de impedir la fiscalización judicial de esos actos.

\section{Administración Pública, intereses generales e interés público 1 Etapa predemocrática}

Con anterioridad a la Constitución de 1978 los esfuerzos de la doctrina científica, que influyeron en la jurisprudencia y en la legislación, se dirigieron a lo que de un modo gráfico se denominó el "Estado administrativo de Derecho". ${ }^{19}$ Como muestras de esa orientación consciente ha destacarse la "lucha contra las inmunidades del poder" y la insistencia en su reducción y en el control judicial de la actuación de la Administración, con empeño especial en el de las disposiciones generales enmanadas de la Administración. ${ }^{20}$

${ }_{14}$ Cfr. HEGEL, G. W. Friedrich, Principios de la filosofía del Derecho, 2a ed., trad. Española, Edhasa, Barcelona, 1999. "El Estado es la realidad efectiva de la idea ética, el espíritu ético como voluntad sustancial revelada" (p. 370) "El Estado en y por sí es la totalidad ética" (p. 375) "El Estado es voluntad divina en cuanto espíritu presente que se despliega en una figura real y en la organización de un mundo".

15 Cfr. para España, MARTIN-RETORTILLO, L. La cláusula de orden público como límite -impreciso y creciente- del ejercicio de los derechos, Civitas, Madrid, 1975.

${ }^{16}$ El Conseil d'Etat se somete al titular del poder en el conocido arrêt Laffite de 1 de mayo de 1822, relativo a la reclamación de la renta concedida por Napoleón a su hermana Paulina Borghese.

17 En España la LJCA de 1956 excluía de la jurisdicción contencioso-administrativa "los actos políticos del Gobierno" como los que afectan "a la seguridad interior del Estado". Con base en ese precepto existieron pronunciamientos judiciales que calificaron como tales actos que procedían del gobierno, como la convocatoria de un concurso (STS de 10 de febrero 1960) que no ofrecen hoy duda alguna de que son actos administrativos. La categoría ha desaparecido del ordenamiento jurídico español como corrobora la jurisprudencia del Tribunal Constitucional (Ad exemplum STC 45/1900, STC 220/1991).

18 Así ocurría en la Ley de 13 de septiembre de 1888 reformada en 1944 hasta la Ley de 1956.

19 La expresión es de GARRIDO FALLA. Como muestras de lo que se afirma en el texto pueden citarse la ley de la Jurisdicción contencioso-administrativa de 27 de diciembre de 1956 en gran medida redactada por los profesores M. BALLBÉ y J. GONZÁLEZ PÉREZ, las leyes de Régimen jurídico de la Administración del Estado de 1957 que generaliza la responsabilidad patrimonial objetiva del Estado, y la ley de Procedimiento administrativo de 1958, impulsadas por L. LÓPEZ RODÓ.

${ }^{20}$ Cfr. GARCÍA DE ENTERRRÍA, E., Legislación delegada, potestad reglamentaria y control judicial, Tecnos. Madrid, 1970 que recoge varios trabajos. "La lucha contra las inmunidades del poder en el Derecho administrativo", RAP, n. 38, (1962). 
La LJCA de 1956 contribuyó decisivamente a ese cambio. En su luminosa exposición de motivos, haciéndose eco de la jurisprudencia, declara que los actos discrecionales no están excluidos de fiscalización contencioso-administrativa. La discrecionalidad no se refiere "a un acto en bloque", surge "cuando el ordenamiento jurídico atribuye a algún órgano competencia para apreciar, en un supuesto dado, lo que sea de interés público". Un interés público que ha de ser justificado y no meramente presumido, no inherente a la forma o naturaleza de la decisión de la Administración y, por tanto, también obligado para las normas reglamentarias. Esa preocupación domina en la doctrina de la época ${ }^{21}$ y en ese sentido, se califica el interés público como un concepto jurídico indeterminado. ${ }^{22} \mathrm{El}$ interés público se concibe fundamentalmente como criterio de legalidad, en línea con la doctrina foránea.

De alguna manera esa línea, que ha sido enormemente positiva en el avance hacia un real Estado de Derecho, estaba condicionada por el papel que se adjudicaba a la Administración pública en el ordenamiento jurídico y en la misma construcción científica del Derecho administrativo.

El artículo 40 de la ley Orgánica del Estado de 10 de enero de $1967^{23}$ decía que "la Administración... asume el cumplimiento de los fines del Estado en orden a la pronta y eficaz satisfacción del interés general". A la comprensión cabal de ese texto ayuda lo que decía el artículo 1 de la ley de régimen jurídico de la Administración del Estado. Esta, constituida por órganos jerárquicamente ordenados, "actúa para el cumplimiento de sus fines con personalidad jurídica única".

De acuerdo con una tradición que hunde sus raíces en postulados de los revolucionarios franceses ${ }^{24}$ y que no disuena de la Administración como "único poder personificado del Estado", la doctrina dominante

${ }^{21}$ Cfr. GARCÍA DE ENTERRÍA, E., "La interdicción de la arbitrariedad en la potestad, reglamentaria" RAP, n. 30, (1959). La restricción de la legitimación para recurrirlas hacía fácil camuflar actos plúrimos bajo su cobertura para impedir la fiscalización contenciosa. Cfr. MEILÁN GIL, J. L., La distinción entre norma y acto administrativo, ENAP, 1967.

${ }^{22}$ Cfr. SÁINZ MORENO, F., "Reducción de la discrecionalidad: el interés público como concepto jurídico", REDA, n. 8, (1976), con cita de bibliografía alemana, francesa e italiana. Del mismo autor "Sobre el interés público y la legalidad administrativa", (En torno a la obra de TRUCHET, Les functions de la notion d'interêt général dans la jurisprudence du Conseil 'Etat), RAP, n. 82, (1977).

${ }^{23}$ Una ley fundamental, sucedánea de una norma constitucional, impulsada por L. LÓPEZ RODÓ.

${ }^{24}$ Cfr. MEILÁN GIL, J. L. "Sobre el acto administrativo y los privilegios de la Administración" (1986), en Administración Pública en perspectiva, Universidade da Coruña, 1997, pp. 391 y ss, "El acto administrativo como categoría jurídica" (AC, Revista de Direito administrativo constitucional, n. 38, (2009), pp. 16-18). 
pone el acento en la Administración Pública, utilizando un criterio subjetivo para la definición del Derecho administrativo. ${ }^{25}$

En aquella etapa, en la inevitable posición que había de adoptarse para definir el Derecho administrativo en los concursos para acceder a una Cátedra puse, en cambio, el acento en lo que entonces denominé intereses colectivos. ${ }^{26}$

La preocupación fundamental que latía en esa toma de posición era evitar las consecuencias que podrían derivarse de la identificación de Administración pública e interés general, de la consideración de aquella como un dominus a lo que ayudaban los privilegios heredados del Antiguo Régimen, que como poder - Hauriou es una referencia , se les reconocía. De ahí la insistencia en el "carácter subordinado de la Administración como titular de la gestión de intereses colectivos".27 En definitiva, "se trata de poner el acento primariamente en los intereses colectivos y secundariamente en la Administración personificada", decía - en una clara divergencia con la doctrina dominante. Esa posición mantenida en 1967 entroncaría con naturalidad en la Constitución de 1978 en cuya redacción intervine directamente.

\section{El paradigma constitucional}

\subsection{La Administración Pública como servidora de los intereses generales}

La Constitución de 1978 va a proporcionar un vuelco a la consideración de los intereses generales. El artículo 103, 1 dice que "la Administración Pública sirve con objetividad los intereses generales y actúa de acuerdo con los principios de eficacia..., con sometimiento pleno a la ley y al Derecho".

Puedo dar una interpretación cuasiauténtica del precepto cuya redacción inicial se refería significativamente a los intereses colectivos. El cambio, introducido con absoluta conciencia, viene significado por la idea de servicio que se asigna a la Administración Pública, lejos de la ambigüedad del asumir de la predemocrática ley orgánica del Estado,

\footnotetext{
${ }_{25}$ Cfr. GARCÍA DE ENTERRÍA, E., Curso de Derecho administrativo, t. I, Civitas, Madrid, 6a ed., 1993, pp. 38 y ss. El Derecho administrativo es el Derecho propio y específico de las Administraciones Públicas en cuanto persona. Un Derecho estatutario, hecho de un equilibrio entre privilegios y garantías.

${ }^{26}$ MEILÁN GIL, J. L., El proceso... pp. 84-85. "El Derecho administrativo podría ser considerado como unidad conceptual expresada en esas dos palabras y no como la agregación de Derecho y Administración". Lo que modula el género es lo administrativo, la toma en consideración de los intereses colectivos... Derecho común -como lo es el Derecho civil- relativo a la "regulación y gestión subordinada de intereses colectivos".

27 Ibidem, pp. 74-77, con citas de RIVERO, GIANNINI, WOLF y VILLAR PALASÍ.
} 
con las posibles - y reales - interpretaciones del monopolio y posesión del interés general por la Administración Pública. No es "señora del interés general". Por el contrario está a él vinculada. Desde esta interpretación constitucional no goza de una presunción indiscriminada de que su actuación es conforme al interés general. EL interés general - o el público - no es un manto que cubre cualquier actuación de las Administraciones públicas. La apelación al interés público requiere que sea justificado, motivado, probado por la Administración.

El sometimiento no sólo a la ley sino al Derecho rebasa la mera relación del interés general con la legalidad. Es con todo el ordenamiento jurídico, encabezado por la Constitución $y$, por tanto, con los principios constitucionales $y$, por supuesto, con los principios generales del Derecho. El carácter pleno del sometimiento - con el que se refuerza el cometido servicial de la Administración - barre de un plumazo toda inmunidad de poder.

El artículo 106, 1 refuerza la interpretación expuesta: "Ios Tribunales controlan la potestad reglamentaria y la legalidad de la actuación - no sólo actos administrativos, sino el comportamiento que incluye la inacción - administrativa, así como el sometimiento de ésta a los fines que la justifican", que encuentran una referencia última en servir los intereses generales. ${ }^{28}$ En consecuencia, el control judicial de la potestad - no necesariamente identificable con privilegio - por el fin que la justifica hace innecesario acudir a una referencia genérica al interés público. La potestad es mensurable desde el fin concreto asignado en el ordenamiento jurídico - mediante ley y su desarrollo reglamentario - en relación al quantum, el cómo, incluso el cuando, en cuyo enjuiciamiento operan principios generales como la proporcionalidad, la razonabilidad. Es la Administración la obligada a razonar el empleo de la potestad en los términos en que lo hace. No hacerlo, o no hacerlo de un modo razonablemente sólido supone la violación directa del principio hoy constitucional (artículo 9,3) de interdicción de la arbitrariedad. Su actuación, controlable judicialmente, sencillamente no es conforme a Derecho, sin necesidad de acudir a una actuación contraria a un genérico interés público. La concreción de ese fin en cada caso de ejercicio de la potestad es lo relevante para el control de ésta.

${ }_{28}$ No se insiste en el análisis de la nota de "objetividad" que refuerza la negación del título dominical de la Administración sobre los intereses generales como interés propio. 
2.2 Los derechos fundamentales son el núcleo irreductible de los intereses generales

Complemento indispensable y esencial de lo expuesto es el reconocimiento que se hace de los derechos fundamentales de un modo implícito en el artículo 9, 1 según el cual "los ciudadanos y los poderes públicos - uno de ellos la Administración Pública - están sujetos a la Constitución y al resto del ordenamiento jurídico" y de un modo explícito en el artículo 53, 1 al decir que esos derechos ${ }^{29}$ "vinculan a todos los poderes públicos" y el legislador "en todo caso deberá respetar su contenido esencial".

El antecedente de estos preceptos en el ordenamiento español se debe a una enmienda de mi autoría, que ligeramente retocada se incorporó a la ley para la reforma política de 1977 aprobada en referéndum nacional, que hizo posible la celebración de las primeras elecciones democráticas $y$, en consecuencia, las Cortes constituyentes que aprobaron la Constitución de 1978. Decía así: "los derechos fundamentales son inviolables y vinculan a todos los órganos del Estado".30 En su defensa en sede parlamentaria se reconoce la inspiración en la ley fundamental de la República federal alemana, cuyo artículo 1, 3 al referir se a los derechos fundamentales que se enumeran dice que "vinculan a los poderes legislativo, ejecutivo y judicial como derecho directamente aplicable".

En la justificación de la enmienda estaba el recuerdo de lo acaecido bajo la Constitución de Weimar, que permitió el "sarcasmo democrático del nazismo... Por encima del voluntarismo coyuntural de una mayoría parlamentaria está el respeto de los derechos fundamentales de la persona. Esto es parte esencial de la democracia porque supone tanto como el respeto para las minorías una garantía frente la arbitrariedad formalmente democrática del Poder".31

De un modo sentencioso, no los derechos - fundamentales - en el marco de la ley, sino la ley en el marco de los derechos fundamentales,

\footnotetext{
${ }^{29}$ Los derechos y libertades reconocidos en el Capítulo Il del título I.

30 HERNÁNDEZ GIL, A., El cambio político español y la Constitución, Madrid, 1982, pp. 148, la calificó como "un correctivo al voluntarismo jurídico y a la omnímoda hegemonía de la ley". En términos también elogiosos, GONZÁLEZ PÉREZ, J. La dignidad de la persona, Civitas, Madrid, 1986, pp. 75 y ss., "importante norma por lo general olvidada" (Cfr. GONZÁLEZ NAVARRO, La nueva ley fundamental para la reforma política, Madrid, 1977, pp. 107 y ss). La importancia es destacada por Pilar y Alfonso FERNÁNDEZ-MIRANDA, Lo que el Rey me ha pedido, Barcelona, 1995, pp. 261 que la juzgan "de gran trascendencia".

31 Cfr. Anexo al núm. 1538 del Boletín Oficial de las Cortes, pp. 148.
} 
con eco también en la doctrina alemana, aunque de un modo más matizado. $^{32}$

Desde muy temprano el Tribunal Constitucional dejó claro que los derechos fundamentales no son sólo derechos subjetivos, sino "elementos esenciales de un ordenamiento objetivo de la comunidad", más aún, "en cuanto elemento fundamental de un ordenamiento jurídico... dan sus contenidos básicos a dicho ordenamiento",33 del que forman parte al estar positivizados en la Constitución. ${ }^{34}$ La protección de los derechos fundamentales es un "destacado interés general".35 De acuerdo con su doble naturaleza subjetiva y objetiva, "no incluyen solamente derechos subjetivos de defensa de los individuos frente al Estado y garantías institucionales sino también deberes positivos por parte de éste... obligación positiva de contribuir a la efectividad de tales derechos y valores que representan", ${ }^{36}$ con apoyo general en el artículo 9, 2 CE concretado en otros. $^{37}$

La primera consecuencia que se deriva de lo expuesto es que los derechos fundamentales forman parte de los intereses generales, constituyen su "núcleo duro" que los poderes públicos y, en concreto la Administración, han de servir, no sólo respetándolos, sometidos a ellos por ser Derecho, sino como guía de su actuación para hacer que sean "reales y eficaces" en la expresión del artículo 9, 2.

Una segunda consecuencia se refiere a la construcción del Derecho administrativo, alejada de la síntesis de Hauriou: "prerrogativa de la Administración y equidad". Privilegios y prerrogativas no se compadecen ya con la orientación constitucional, aunque se resistan a desaparecer. No tiene sentido seguir manteniendo la defensa de las potestades de la Administración como algo exorbitante del Derecho privado. Forman parte necesaria de la función encomendada constitucionalmente a la Administración pública y esencial del Derecho administrativo. Así se ha visto también por lúcida jurisprudencia desde hace años: "La potestades que la Constitución y las leyes encomiendan a la Administración

32 Cfr. KRÜGER, H., Grundgesetz und Kartellgesetzgebung, 1950, pp. 12: "antes — se refiere a Weimar — los derechos fundamentales sólo valían en el ámbito de la ley", hoy - se refiere a Bonn — "las leyes sólo valen en el ámbito de los derechos fundamentales".

33 STC de 14 de julio de 1981.

34 STC 56/1982 de 26 de julio.

35 STC 93/1984 de 16 de octubre.

36 STC 53/1985 de 11 de abril.

37 Ad exemplum, artículo 27 CE en relación con las obligaciones de los poderes públicos para que el derecho a la educación sea real y efectivo. 
no son privilegios, sino instrumentos normales para el cumplimiento de sus fines $y$, en definitiva, para la satisfacción de los intereses generales". ${ }^{38}$

En la confrontación entre privilegios de la Administración y derechos fundamentales de la persona prevalecen estos. De otro modo la Administración no estaría utilizando su potestad al servicio del interés general, definido primariamente por los derechos fundamentales. ${ }^{39}$ La aplicación directa de la Constitución, en la que figura el derecho fundamental a la presunción de inocencia (art. 25), debería arrumbar definitivamente la categoría de relaciones especiales de sujeción o de sujeción especial. ${ }^{40}$

\subsection{Intereses generales como parámetro de la estructura del Estado autonómico}

Junto el reconocimiento de los derechos fundamentales que acaba de exponerse, la configuración del Estado social y democrático como autonómico fue la incorporación más complicada a la Constitución. No se trata de analizar su complejidad política y jurídica, ${ }^{41}$ sino de subrayar la función del interés general para delimitar las competencias del Estado y las Comunidades autónomas. ${ }^{42}$ En expresión de Löwenstein, fácilmente asumible, "no hay nada más delicado en la técnica constitucional que la asignación originaria de las tareas estatales a los dos campos de competencias constituidos por el Estado central y los Estados

38 STS de 27 de marzo de 1986.

${ }^{39}$ Cfr. MEILÁN GIL, J. L. "Sobre el acto..." pp. 396 y ss, con crítica del "inencontrable" privilegio de autotutela de la Administración y su proyección en materia de sanciones, ejercicio abusivo de la ejecutividad del acto y de la ejecución forzosa, que podría extenderse a prerrogativas en materia de contratación... Por las mismas consideraciones, el dominio público no ha de considerarse como una propiedad pública, las actas de las inspecciones no gozarían de presunción de veracidad y en definitiva, el lugar central del Derecho administrativo no sería el acto administrativo sino los derechos fundamentales de las personas, tutelados por las potestades de la Administración.

40 De importación alemana y allí en claro retroceso y todavía admitida por el Tribunal Constitucional en España (STC 2/1987; 42/1987; 234/1991; 26/2005; 10/2009) distinguiendo potestad sancionadora y disciplinaria, que solía criticar en las clases con asentimiento de los alumnos a quienes la categoría los incluye con los reclusos en establecimientos penitenciarios, entre otros.

Cfr. MAYER, O, Deutches Verwaltungsrecht, Dunker/Humblot, Berlín 1969, pp 101 y ss. En España el primer trabajo es de GALLEGO ANABITARTE, A. "Las relaciones especiales de sujeción y el principio de legalidad en la Administración", RAP, n. 34, (1961), pp. 11 y ss. Otros de GARCÍA MACHO (1992), LASAGABASTER (1994), PRIETO ALVÁREZ (RAP, 2009). Por la aplicación directa se pronuncia J. M. DÍAZ LEMA (2010) que comparto.

${ }^{41}$ Cfr. MEILÁN GIL, J. L., La ordenación jurídica de las autonomías, Tecnos, Madrid, 1988. La construcción del Estado de las autonomías, Un testimonio personal, Fundación Caixa Galicia, A Coruña, 2002 en donde queda reflejada, con testimonios ajenos, mi intervención personal en los puntos decisivos del título VIII y disposición transitoria segunda de la Constitución dedicados al Estado autonómico, que consta también en las Actas del Congreso de los Diputados.

42 LÖWENSTEIN, K., Teoría de la Constitución, ed. española, Barcelona, 1976, pp. 356-58. SCHWARTZ, A commentary on the Constitution of United States, Nueva York, 1963, pp. 7-10. 
miembros".43 La complejidad política y jurídica se revela en el abundante número de sentencias del Tribunal constitucional resolviendo recursos de inconstitucionalidad y conflictos de competencia constitucionales, en cuya solución no es ajena una determinada orientación política. ${ }^{44}$

Para lo que aquí interesa bastará con recordar que el gobierno, con mayoría en el Senado, podrá imponer medidas a una Comunidad autónoma que "actuase de forma que atente gravemente al interés general de España" (art. 155) y se prevé la posibilidad de leyes del Estado para armonizar competencias de las Comunidades autónomas, "cuando así lo exija el interés general" (art. 150, 3). ${ }^{45}$

Conviene advertir que la simple invocación del interés general no es legitimadora de la competencia estatal porque "podría terminar por vaciar el diseño constitucional del Estado de las autonomías".46 El interés general puede ser servido por las Comunidades autónomas, para lo que se les reconocen competencias exclusivas, aunque se requiera siempre una articulación con competencias estatales. ${ }^{47}$ El interés general viene referido por el carácter territorial, porque la actividad rebasa el territorio de una comunidad autónoma o por determinación legal que habilita al gobierno para su alteración. ${ }^{48}$

\subsection{La determinación del interés general}

De lo expuesto se desprende que la determinación de lo que sea interés general se realiza primariamente en la Constitución de un modo directo por lo que se refiere a los derechos fundamentales o habilitando al Parlamento o al gobierno para que actúe de acuerdo con él en los supuestos previstos. Es la Constitución la que habilita al Parlamento,

43 La "ley orgánica de armonización del proceso autonómico", que pretendía "racionalizarlo" a favor de las competencias del Estado, que como parlamentario de la mayoría no voté, fue declarada inconstitucional en lo fundamental por STC de 5 de agosto de 1983. Cfr. MEILÁN GIL, J. L., La configuración... pp. 231 y ss.

${ }^{44}$ El Presidente que fue del Tribunal Constitucional F. TOMÁS Y VALIENTE, al enjuiciar la doctrina del Tribunal Constitucional en su etapa declaró que "una línea jurisprudencial abiertamente autonómica hubiera podido poner en peligro un Estado que, antes de autonómico, ha de continuar siendo un Estado", El reparto competencial en la jurisprudencia del Tribunal Constitucional, Madrid, 1988, pp. 146.

45 La importante STC 76/1983 de 5 de agosto declaró la inconstitucionalidad de lo fundamental de la única ley de armonización aprobada porque ese artículo es "una norma de cierre del sistema" que sólo puede aplicarse cuando no sea posible de otra manera garantizar "la armonía del interés general", que ya fue tenido en cuenta por el constituyente al fijar el sistema de distribución de competencias.

46 STC 146/1986 de 25 de noviembre.

${ }^{47}$ Es lo que sucede con el urbanismo en relación con la igualdad de condiciones en el ejercicio del derecho de propiedad según la importante STC 61/19997 de 20 de marzo.

${ }^{48}$ Cfr. STC 40/1998 de 19 de febrero: Puertos de interés general, competencia del Estado son "puertos que desarrollan una actividad relevante para el conjunto del Estado de carácter comercial o de otro tipo de acuerdo con lo dispuesto en el artículo 5 de la Ley 27/1992 de puertos del Estado y de la marina mercante".

La doctrina de esa sentencia se aplica a aeropuertos en STC 204/2002 de 31 de octubre. 
para que por la ley se establezcan deberes a los ciudadanos en función del interés general, explícitamente (servicio civil, art. 30) o implícitamente (tributos y prestaciones patrimoniales, art. 31) o con la expresión equivalente de utilidad pública justificadora de la expropiación forzosa de bienes y derechos (art. 33).

Igualmente a través de la ley - estatal o autonómica - se concretarán los principios rectores de la política social y económica (capítulo III del Título I) ${ }_{1}^{49}$ que informarán también la práctica judicial y la actuación de la Administración como poder público (art. 53, 3).50

La ley puede establecer lo que es de interés general en un determinado sector remitiendo a la Administración su desarrollo y concreción. ${ }^{51}$

El interés público o el interés general pueden utilizarse como canon o parámetro para el control judicial de la actuación de la Administración ${ }^{52}$ a partir de los citados principios rectores de la política social y económica que, aunque no recogen derechos fundamentales, han de informar la actuación de la Administración y en ese sentido, determinan lo que son intereses generales al concretarse en los programas políticos de los gobiernos, ${ }^{53}$ de acuerdo con la alternancia democrática y la legitimidad que deriva de unas elecciones, en la procura de la calidad de vida de los ciudadanos.

En ese sentido podría hablarse de un principio general de tutela al servicio del interés general.

Numerosos son los casos en que la jurisprudencia aplica ese canon de enjuiciamiento: en materia de urbanismo (STS de 31 de mayo de 1995, sometimiento a las exigencias del interés público), de transportes (STS de 11 de abril de 1995 "obedece al más elemental enjuiciamiento de la realidad social y la conveniencia del interés público estimar como

\footnotetext{
49 Se refieren a asuntos tan importantes como la protección de la familia, derecho a la salud, al medio ambiente, vivienda, seguridad social, defensa de consumidores y usuarios.

50 Esos principios no son "normas sin contenido", han de ser tenidos "presentes en la interpretación tanto de las restantes normas constitucionales como de las leyes" STC 19/1982 de 5 de mayo, son "previsiones constitucionales que obligan al legislador", incluyen a la legislación de las comunidades autónomas.

51 La STC 112/2006 de 5 de abril declaró que era constitucional la consideración de la Ley 21/1997 de 3 de julio reguladora de las emisiones y transmisiones de competiciones y transmisiones deportivas en cuanto a la consideración de catalogar como de interés general aquellos que tengan "relevancia social", "se celebren con periodicidad, pero no frecuentemente" tengan, "atracción sobre la audiencia" "importancia en el ámbito deportivo nacional" y una cierta "tradición", catalogación que realiza la Administración al inicio de cada temporada.

52 Cfr. GARCÍA DE ENTERRÍA, E., Democracia, jueces y control de la Administración, 5a ed., Thomson, Cizur Menor.

53 Según el artículo 97 CE "El Gobierno dirige la política interior y exterior, la Administración civil y militar".
} 
necesario un servicio público de transporte de 1982 que en cambio no lo fuese en $\left.1968^{\prime \prime}\right)$.

En materia de apertura de farmacias. La apertura estaba condicionada a la existencia de un núcleo de población de 2000 personas. En Galicia la población está dispersa y se planteaba cómo entender el núcleo. "Lo decisivo, dice el tribunal, es que la nueva instalación suponga un mejor servicio a un núcleo de población con independencia de las características, físicas o materiales sobre las que se asienta la población" (STS de 18 de mayo de 1989). Domina en la materia el principio "pro apertura", para una mejor atención sanitaria, como reclama el interés general, frente al corporativista de los anteriores titulares de farmacias.

El mismo criterio del fin, consecución eficaz del interés general, es lo que ha de justificar la creación de una empresa pública, además de someterse a las "reglas de la libre competencia que rige el mercado" (STS 10 de octubre de 1989, RJ 7352).

Paradigmática es la jurisprudencia recaída en relación con los servicios esenciales que deben asegurarse por la Administración en caso del ejercicio del derecho constitucional de huelga. La actuación administrativa se juzga "en función de los intereses generales que ha de servir" (STS de 11 de abril de 2003, RJ 3705).

El Tribunal Supremo o los Tribunales Superiores de Justicia en las Comunidades, al estimar el recurso de casación en interés de la ley, ${ }^{54}$ por vía negativa pueden determinar lo que sea de interés general ya que el recurso se interpone contra sentencias consideradas "gravemente dañosas por el interés general". Este se identifica con la correcta interpretación y aplicación de normas estatales o autonómicas..$^{55}$ La ampliación de la legitimación al Fiscal, inicialmente limitada a la representación de la Administración "generaliza" el interés general, tradicionalmente referido a que la Administración no soporte en el futuro un daño de carácter económico. ${ }^{56}$ Se rebaja así el carácter de confrontación con el interés particular, aunque sea de colectivos o de grupo. ${ }^{57}$

El recurso "cumple una función monofiláctica en defensa del interés general".58 El interés general se identifica con el interés de la ley.

54 Artículos 100 y 101 de 1998.

55 En el caso del Tribunal Supremo se fija "la doctrina legal".

56 Cfr. STS de 19 de junio de 1995.

57 Tradicionalmente se consideraba el recurso como "un último remedio que el legislador ha puesto a disposición de la Administración Pública, como representante y gestora que es de los intereses generales" STS 11 de diciembre de 1997.

58 STS de 12 de mayo de 1994. 
IV Interés general y conformidad a derecho de la actuación de la administración

Los preceptos de la Constitución analizados con anterioridad permiten deducir que la apelación al interés público como categoría jurídica ha perdido virtualidad para garantizar la legalidad de la actuación administrativa y su control judicial. No es preciso aludir a él para someter a Derecho la potestad discrecional de la Administración. El sometimiento pleno no sólo a la ley sino también al Derecho, en el que ha de incluirse la Constitución, hace innecesaria la invocación del interés público. Principios constitucionales, como la interdicción de la arbitrariedad - y la consecuencia de obligatoriedad legal de la motivación - y principios generales - igualdad, confianza legítima en la Administración y buena fe, proporcionalidad - permiten someter a Derecho la discrecionalidad de la Administración. $Y$, por supuesto los derechos fundamentales, entre los que el de la tutela judicial efectiva (art. 24 CE) cobra una especial importancia, en lo que no es del caso insistir.

De otra parte, esa misma conformidad a Derecho y su control judicial viene facilitada por el precepto constitucional que vincula la actuación de la Administración, el ejercicio de su potestad, al fin concreto y específico que lo justifica en cada caso y no sólo genéricamente como puede reconocerse al interés general $\mathrm{o}$ al interés público. Vale para enjuiciar la aplicación de la norma como para el ejercicio de la potestad reglamentaria Su límite es que "el contenido de la norma no sea incongruente o contradictorio con la realidad que se pretende regular, ni con la naturaleza de las cosas o la esencia de la institución".59

Salvados por la Constitución los obstáculos para el control judicial de la discrecionalidad de la Administración parece que habrá de reducirse el ámbito de la categoría interés general o interés público. Llevando la consideración del interés general hasta el extremo, los actos de la Administración declarados nulos lo serían por vulnerar el interés general y lo mismo podría decirse de la inconstitucionalidad de las leyes. Los supuestos de nulidad y los vicios de los actos serían algo superfluo.

Por eso, entiendo que la modificación de los contratos administrativos prevista legalmente, aunque en último término está fundada en

\footnotetext{
59 STS de 19 de febrero de 2008. Se trataba de un reglamento de protección de familias numerosas que se anuló parcialmente porque algunos de sus preceptos, paradójicamente, no eran adecuados a la protección declarada.
} 
el omnipresente interés público, se encuentra conectada de un modo inmediato al fin específico del contrato al que está vinculada la potestad de la Administración. La referencia al interés público va acompañada de concretas determinaciones legales para impedir la utilización espuria de esa prerrogativa de la Administración. ${ }^{60}$

Lo que pretendía conseguirse y en gran medida se ha logrado con la utilización del interés público como un concepto jurídico indeterminado ${ }^{61}$ es hoy posible con mayor seguridad sin acudir a él y sin necesidad de forzar la configuración jurídica de la discrecionalidad.

Para la doctrina científica dominante, de la que se ha hecho eco la jurisprudencia, la discrecionalidad supone una pluralidad de soluciones "igualmente justas", en tanto que el concepto jurídico indeterminado se identifica sólo con una. ${ }^{62}$ De ahí la importancia innegable de considerar como tal el interés público. Ciertamente lo es. Desde el punto de vista del interés general al que la Administración debe servir por imperativo constitucional sólo existe una solución justa. ${ }^{63}$ La diferencia entre discrecionalidad y concepto jurídico indeterminado proviene del fundamento de la decisión, de acuerdo con lo contenido - y su modo de expresión - en la norma. La discrecionalidad responde a un proceso volitivo, en tanto que el concepto jurídico indeterminado a uno de conocimiento que se manifiesta en la constatación. En todo caso, la realidad constatable no admite, por su propia naturaleza real, una pluralidad. Sería un contrasentido. Es la que es. Cosa distinta es la dificultad de su conocimiento o constatación. ${ }^{64}$

Desde esta perspectiva el interés público es conformidad con la legalidad, con el Derecho. Esa conformidad es lo que se aprecia de un modo positivo o negativo en la resolución de los recursos interpuestos contra los actos dictados en ejecución de una potestad discrecional. Lo que se solicita en el petitum de esas demandas es la declaración de no conformidad

${ }_{60}$ Artículo 202 de la Ley 30/2007 de contratos del sector público de 30 de octubre, Cfr. MEILÁN GIL, J. L, La estructura... pp. 241-248.

${ }^{61}$ Cfr. SÁINZ MORENO, F., "Reducción...”

${ }^{62}$ Cfr. MEILÁN GIL, J. L., La estructura de los contratos públicos, lustel, 2008, pp. 230-33, a propósito de los criterios de valoración para la adjudicación de los contratos.

${ }^{63}$ Con razón la STS citada de 13 de junio de 2000 se pregunta "si en un Estado de Derecho puede admitirse la existencia a priori de algo indiferente jurídicamente".

${ }^{64}$ Por eso, no es de extrañar que se hable "de un amplísimo criterio de discrecionalidad administrativa en cuanto a los extremos puramente técnicos" STS de 5 de marzo de 2002 (RJ 2002/2565), o que existe un margen de discrecionalidad para la interpretación y aplicación razonable de las cláusulas. STS de 11 de julio de 2006 (EDJ 2006/109862). 
a Derecho del acto que se impugna, como evidencia una amplísima y variada jurisprudencia de cita innecesaria.

Esa finalidad queda también patente en la utilización de la acción popular que es "exigir de la Administración el cumplimiento de lo dispuesto en la normativa","5 "exigir la observancia de la legislación urbanística","66 no persiguiendo sólo intereses privados "al margen por completo de la defensa objetiva de la legalidad".67

Algo equivalente puede decirse de la declaración de lesividad para el interés público que es un requisito previo para la pretensión de la Administración de demandar la nulidad del acto ante la jurisdicción contencioso-administrativa. ${ }^{68}$

V Intereses generales e interés público en la suspensión y revocación de actos administrativos

En los supuestos de suspensión, ${ }^{69}$ y revocación de los actos administrativos es donde opera la categoría del interés público sin el canon inmediato de legalidad. En la primera se decide sin entrar en el enjuiciamiento del fondo del asunto, sobre la conformidad o no a Derecho del acto. En la segunda, se opera al margen de un proceso, aun cuando, como es lógico, la revocación será susceptible de control, habida cuenta de las limitaciones establecidas en la ley, una de las cuales es que no sea contraria al interés público. ${ }^{70}$

No es del caso subrayar la importancia de la Constitución en la regulación de las medidas cautelares en el orden jurisdiccional, que han pasado de ser una excepción a la expresión del derecho fundamental a la tutela judicial efectiva y que no se limitan a la suspensión de la ejecutividad del acto. ${ }^{71}$

En relación con lo que se está tratando, la ley del 1998 dispone que la medida cautelar podrá únicamente acordarse cuando, previa valoración de todos los intereses en conflicto, la ejecución del acto o la aplicación de la disposición "pudieran hacer perder su finalidad

\footnotetext{
${ }^{65}$ De vías pecuarias, STS de 4 de diciembre de 2007.

66 STS de 10 de noviembre de 2004.

${ }_{67}$ STSJ Cantabria, de 28 de mayo de 2007.

68 Artículo 43 de la LJCA. La Administración ha de aportar prueba tendente a acreditar los hechos en que se funda la declaración; en caso contrario prevalece la presunción de validez del acto. STS de 2 de diciembre 2008.

${ }^{69}$ Es posible en vía administrativa la suspensión de la ejecución (art. 111, 2 de la LRJPAC) y en vía jurisdiccional. En el texto se tratará sólo de esta.

70 Artículo 105 de la Ley 30/1992, LRJPAC.

71 En ese sentido, antes de la LJCA de 1998, MEILÁN GIL, J. L., "La suspensión jurisdiccional de los actos administrativos", Revista andaluza de Administración Pública, n. 28, (1996), pp. 11 y ss.
} 
legítima al recurso". Y podrá denegarse cuando de ella "pudiera seguirse perturbación grave a lo intereses generales o de tercero". El primer criterio es expresión del conocido periculum in mora. El segundo es "contrapeso o parámetro de contención del anterior criterio".72

En definitiva, el interés general ha de ser ponderado por el Tribunal o juez tanto para acordar la suspensión, como de una manera específica para denegarla si su otorgamiento pudiera ocasionar daño grave. La confrontación se plantea entre interés general e intereses particulares o entre diferentes intereses generales o públicos.

\section{Intereses generales e intereses privados}

La consideración del derecho fundamental a la tutela judicial efectiva ha supuesto una apreciación más ajustada de lo que sean intereses generales. Estos no tienen que ser identificados con el principio de ejecutividad del acto administrativo, que encuentra su fundamento constitucional en el de la eficacia con la que la Administración ha de servir a los intereses generales, "normalmente inherentes a toda decisión administrativa".73 En la confrontación de estos con los intereses particulares es preciso un "plus". Para impedir la suspensión no basta con alegar su repercusión en el interés general. ${ }^{74} \mathrm{Ha}$ de motivarse que de ella se seguiría un daño grave, más específico que la no ejecutividad del acto en general.

Con anterioridad a la vigente ley de 1998 el criterio fundamental era la imposibilidad o dificultad en la reparación del daño causado. ${ }^{75}$ En la actualidad el centro se encuentra en la posible pérdida de razón del proceso en el que se inserta el incidente de la medida cautelar. Quien pide la suspensión ha de aducir esa pérdida, que es lo prioritario ${ }^{76}$ y la Administración para impedirla ha de invocar que la suspensión ocasionaría un daño grave para el interés general. La decisión queda en

72 STS de 20 de mayo de 2009, con un excelente resumen de la doctrina jurisprudencial.

73 ATS de 18 de diciembre de 2009.

74 "Como sería la trascendencia social que tiene la potestad sancionadora en materia de dopaje en el deporte... es precisa una lesión más específica al interés general" (STS de 6 de mayo de 2009).

75 La referencia al interés general, que figuraba en la exposición de motivos de la ley de 1956, fue adquiriendo mayor importancia en la jurisprudencia (Cfr. RODRÍGUEZ-ARANA, J., La suspensión del acto administrativo, Montecorvo, Madrid, 1986. CHINCHILLA MARIN, C. La tutela cautelar en la nueva justicia administrativa, 1991. JIMENEZ PLAZA, C., El humus boni iuris, Un análisis jurisprudencial, lustel, Madrid, 2005) "en detrimento del justiciable y en garantía de los bienes patrocinados por la Administración" (p. 43).

La suspensión solía otorgarse en órdenes de demolición, cierre de establecimientos, desalojos de viviendas, expulsión de extranjeros, suspensión del ejercicio profesional...

76 "La finalidad legítima del recurso es no sólo, pero sí prioritariamente, la efectividad de la sentencia que finalmente haya de ser dictada en él" STS de 18 de noviembre de 2003. 
manos del Tribunal al enjuiciar cada caso concreto. El interés general es determinado por el Tribunal contencioso-administrativo, al hilo de cada caso, como indica el precepto legal al referirse a la valoración o ponderación "circunstanciada".77

El interés general o interés público no está exento de una instrumentalización política. Un ejemplo relevante lo proporcionan unos autos del Tribunal Supremo recaidos en un proceso que enfrentaron a muy importantes empresas del sector eléctrico. El recurso se interpone por una empresa española contra la autorización de una OPA (oferta pública de acciones), por la Comisión Nacional del Mercado de Valores, presentada por otra de la misma nacionalidad y sector. La suspensión otorgada por un primer auto del Tribunal es levantada por un auto posterior a petición de la recurrente con ocasión de otra OPA más beneficiosa presentada por una empresa alemana.

A la suspensión se había opuesto el representante de la Administración por entender que ocasionaría daños graves a los intereses generales, para la competencia y presumiblemente, por tanto, para los usuarios aunque la absorción perseguida por la OPA tendía a disminuir la competencia. Para la empresa - y en realidad para el Tribunal - lo definitivo era la pérdida de razón del proceso, ya que de acordarse la suspensión se habría producido la desaparición de la empresa al ser absorbida por la que había presentado la OPA.

La suspensión se levanta a petición de la empresa que la había solicitado a la vista de la mejor oferta de la empresa alemana. El representante de la Administración apoya el levantamiento con el argumento, que fue decisivo para la nueva mayoría del Tribunal, del principio dispositivo del proceso. Por lo visto ya no perjudicaba a la competencia. Esto se explica desde el ámbito de los intereses del gobierno. Estaba detrás de la primera, en contra de la alemana y a favor de una tercera hispanoitaliana. Al ser la oferta de esta superior a las anteriores el recurso dejaba de tener interés para la empresa "opada".78 Como reconoce el Tribunal había acuerdo entre las partes. Ha prevalecido el interés de los accionistas frente al de los usuarios que nunca defendió la Administración.

\footnotetext{
77 El interés público se relaciona con la masa de aficionados al deporte del fútbol. STS de 11 de marzo de 1992.

78 Cfr. Un detenido análisis en RODRíGUEZ-ARANA, J. Derecho administrativo español, t. I., Netbiblo, A Coruña, 2008, pp. 159 y ss. Las empresas eran ENDESA, GAS NATURAL y la alemana EON. En la actualidad es propiedad de una empresa pública italiana. Los Autos del TS son de 28 de abril de 2006 y 15 de enero de 2007.

También el cambio de mayoría en el Tribunal no está exento de connotaciones progubernamentales.
} 


\section{Conflicto de intereses públicos}

El conflicto de intereses no se da sólo entre los generales y los privados sino entre intereses públicos, uno de los cuales coincide con intereses particulares que es lo que sucede cuanto el particular está amparado por un acto administrativo, trátese de autorizaciones y licencias, o afectado por una disposición. El fenómeno viene facilitado por un Estado compuesto como el autonómico en el que conviven entes locales, comunidades autónomas y Administración general del Estado. Bastará con un breve muestrario de la jurisprudencia reciente.

Se otorga la suspensión cautelar de unos artículos de los Estatutos de la Federación vasca de automovilismo que atribuían a ésta la representación del deporte federado vasco de esas modalidades "en el ámbito estatal e internacional", porque "la imagen internacional de España se vería inevitablemente alterada en un foro de tanta y tan eficaz difusión como es el de las competencias deportivas".79

Un interés general prevalente es, sin duda alguna, el ecológico y medio ambiental del que existen numerosas manifestaciones. En la salvaguarda de ese interés general se ha pronunciado el Tribunal Constitucional para acordar la suspensión de un precepto de una ley autonómica de carácter urbanístico en un recurso de inconstitucionalidad interpuesto para el Gobierno. ${ }^{80}$

La necesidad de superar el trámite de impacto medioambiental condiciona la validez de un proyecto urbanístico. Existen ocasiones en que el proyecto constructivo - centro penitencial del Estado - prevalece sobre ese trámite "por contener - el proyecto - medidas concretas para evitarlo". Predomina el interés estatal sobre el autonómico. ${ }^{81}$

El interés prevalente del dominio público sobre el urbanismo es regla general. ${ }^{82}$ En este ámbito, la suspensión del proceso constructivo que implica la ejecución de un Plan autorizada por una licencia municipal se otorga porque la no suspensión podría originar perjuicios a "los intereses públicos urbanísticos" defendidos por la Administración autonómica. $^{83}$

79 STS de 1 de julio de 2009.

80 ATC de 27 de julio de 2009 en recurso contra ley de Galicia 18/2008 de 29 de diciembre de vivienda.

81 ATS de 13 de julio de 2009. El centro se construye en el País Vasco. Probablemente existió una consideración circunstanciada en la negativa de la suspensión.

82 "La mayor tardanza en el desarrollo urbano de la zona en ningún caso constituye una consecuencia irreversible ni, desde luego, irreparable". STS de 29 de julio de 2009.

${ }^{83}$ STS de 21 de enero de 2009. 
En el mismo sentido en relación con el domino público marítimoterrestre de titularidad estatal, el Tribunal lo considera prevalente en relación con un acuerdo de la Administración autonómica sobre la consideración de núcleo urbano a efectos del deslinde del dominio público, subrayando que el conflicto se da realmente entre dos administraciones aunque existan particulares afectados. ${ }^{84}$

Que no es clara la consideración del interés general prevalente lo demuestran las diferencias de criterio del Tribunal de instancia y el Supremo al decidir sobre la suspensión del acto. No es infrecuente que éste se pronuncie en contra de lo declarado por aquel.

El Tribunal Supremo se muestra a favor de la suspensión sosteniendo que "el interés general derivado del cumplimiento de la normativa sectorial sobre aguas" prevalece sobre "el interés general que el desarrollo urbanístico presenta", lo que implicaba la suspensión de un plan parcial de urbanismo. ${ }^{85}$

En el mismo sentido, en relación con el interés general prevalente de la preservación del patrimonio cultural y eventualmente de la protección del suelo rural frente al que supone una nueva instalación hospitalaria, examinadas las circunstancias y tratarse la suspensión de una modificación meramente "puntual" del Plan de urbanismo. ${ }^{86}$

El interés general del Municipio cede ante el de la Comunidad autónoma y se suspenden unas Normas subsidiarias de urbanismo ${ }^{87}$ o un Plan especial de protección y reforma interior, ${ }^{88}$ por suponer reformas de carácter estructural cuya ejecución llevaría a un resultado material que "no puede más tarde ser remediado sino con dificultades insuperables".

Cuando se trata de disposiciones generales de los Municipios el Tribunal es conciente de la dificultad de establecer los límites que puede ocasionar al interés general la suspensión, por lo que "ha de ser enfocada con la máxima cautela". Lo normal, se afirma, será no acceder a su petición, pero se rechaza, en contra de "respetables opiniones doctrinales", que sea adoptada de "manera automática".89

\footnotetext{
84 STS de 10 de junio de 2009 con cita de otras muchas.

85 STS de 21 de enero de 2009.

86 STS de 3 de febrero de 2009.

87 STS de 18 de diciembre de 2009.

88 STS de 23 de diciembre de 2009 con citas de muchas otras.

89 STS de 10 de febrero de 2009, con cita de ATS de 17 de septiembre de 2001. El automatismo es un residuo de la inimpugnabilidad o de la difícil impugnación jurisdiccional de las disposiciones generales.
} 
El transcurso del tiempo y el cambio de orientaciones políticas ha propiciado la creciente importancia atribuida a la energía eólica que justifica las declaraciones de interés prevalente - y utilidad pública a efectos de expropiación forzosa - respecto de investigaciones mineras, en la línea de mantener el interés general del sistema eléctrico nacional..$^{90}$

\section{El interés público como límite de la revocación}

Los actos de gravamen o desfavorables pueden ser revocados por la Administración en cualquier momento con una serie de limitaciones, entre las cuales figura que no sea contraria al interés público. ${ }^{91}$ En todo caso responde a una apreciación de oportunidad y no de legalidad como ocurre en toda revisión, incluida la de oficio. ${ }^{92}$

Esas limitaciones subrayan el diferente comportamiento, admisible legalmente, de la Administración Pública y los particulares, manifestado en la configuración jurídica del precario. Es doctrina consolidada que las cláusulas de precario en actos administrativos no suponen facultades de la Administración para revisar o modificar o extinguir a libre voluntad el uso anormal autorizado o concedido, "no pudiéndolo hacer arbitriamente" ya que está "obligada a actuar con sometimiento a la ley de acuerdo con el interés público". ${ }^{93}$ Las autorizaciones y concesiones con esa cláusula sólo pueden revocarse "cuando sobrevenga otro interés público incompatible con el que motivó su otorgamiento y que sea preferente al primero".94 Todo ello con vista a la no desposesión arbitraria y, en todo caso, para reconocer la indemnización pertinente.

\section{La permanencia del interés público}

El interés público, con uno $u$ otro nombre, bajo una $u$ otra forma jurídica, en la tradición europea de la que España forma parte, justifica la presencia del poder político en la actividad económica, por referirme a una quaestio disputata. ${ }^{95}$ Es verificable en distintas etapas. ${ }^{96}$ Antes de que se acuñase en el ordenamiento jurídico español la categoría del

90 ATS de 21 de octubre y 14 de mayo de 2008.

91 Artículo 105 LRJPAC.

92 Cfr. MEILÁN GIL, J. L. "La rectificación de errores”, Revista de Estudios de la Vida Local, (1968).

93 STS de 29 de septiembre de 1980.

94 STS de 18 de diciembre de 1997, STS de 29 de septiembre de 1980.

95 Cfr. MEILÁN GIL, J. L. “Una aproximación jurídica a la regulación económica y financiera”, Libro homenaje al profesor Diogo Freitas do Amaral (en prensa).

96 Desde el Código Teodosiano en Roma, a la Novísima Recopilación, ed. de 1985, (libros VII, VIII) en el Antiguo Régimen. 
servicio público ${ }^{97}$ los Municipios tenían la atribución y competencia legal de velar por "los intereses de los pueblos".98 En plena etapa del liberalismo proclamado desde la Constitución de Cádiz persiste la presencia de la Administración municipal. Las resoluciones que se arbitran como consecuencia del progreso, manteniendo la prohibición de monopolio o exclusiva por el contratista del servicio, tienen por finalidad satisfacer los intereses generales de los vecinos..$^{99}$ La configuración clásica de la categoría jurídica del servicio público supone la "publicatio" de la actividad en la feliz expresión de Villar Palasí, la titularidad del servicio en la Administración, aunque su gestión sea llevada a cabo por particulares mediante una concesión, reservándose aquella poderes de policía y potestas variandi además de otras prerrogativas que no es del caso analizar. ${ }^{100}$

Los procesos de privatizaciones en Europa, de acuerdo con la prioridad otorgada al mercado y la desaparición casi total de la expresión "servicios públicos" en el Tratado de la UE han llevado a sostener por una parte de la doctrina científica la desaparición del servicio público o hablar de un nuevo servicio público. ${ }^{101}$ En contra de esa tesis, matizada por alguno de sus autores, ha de recordarse que existen servicios públicos de ámbito estatal (transportes por carretera) y son práctica común en el ámbito municipal.

El poder público, como garante de los intereses generales sigue presente, ${ }^{102}$ a través de la regulación, como en otros tiempos lo hacía con medidas de policía. Incluso para los que en la termología de la Unión Europea se denominan "servicios de interés económico general", más restringidos que los "servicios de interés general", se habla de la "combinación de mecanismos de mercado y misiones de servicio público". 103

La imposición de obligaciones de servicio público es trasunto de una actividad reguladora del Estado, que entronca con - y rebasa - el

97 Cfr. MEILÁN GIL, J. L., "El servicio público como categoría jurídica”, Cuadernos de Derecho público, n. 2, (1997), pp. 75 y ss.

98 Cfr. MEILÁN GIL, J. L. Progreso tecnológico y servicios públicos, Thomson-Civitas, 2006.

99 Cfr. MEILÁN GIL, J. L., La cláusula de progreso en los servicios públicos, Instituto de Estudios Administrativos, Madrid, 1968, pp. 52 y ss. También Progreso...

${ }^{100}$ Cfr. Capítulo II del Título I del libro IV de la Ley 30/2007 de Contratos del sector público.

${ }^{101}$ ARIÑO, G.; DE LA CUETARA, J. M.; MARTÍNEZ LÓPEZ-MUÑÍZ, J. L., El nuevo servicio público, M. Pons, Madrid, 1997.

102 En ese sentido BACELLAR FILLO, Romeu Felipe, Direito administrativo e o novo Código Civil, Editora Forum, Belo Horizonte, 2007, pp. 252-54.

${ }^{103}$ Libro Blanco sobre los servicios de interés general, COM 2004, Introducción. 
concepto tradicional de policía. Resulta obvio que se trata de velar por la seguridad, pero también por la continuidad del servicio y por su calidad, de manera que alcance un nivel previamente fijado y que sea "socialmente aceptable".

Todo ello se pone de manifiesto en el concepto de servicio universal. Se refiere a servicios que se consideran esenciales, de una calidad determinada, asequibles para todos los ciudadanos, con independencia de su situación geográfica, es decir, que el servicio tenga una cobertura territorial completa. En todo caso, tiene un carácter dinámico, atendiendo a la cambiante evolución política, social, económica, y también tecnológica.

La insuficiencia del mercado para cumplir los objetivos sociales que revelan las obligaciones de servicio público se manifiesta en las compensaciones posibles para mantener un equilibrio financiero en la actividad correspondiente. ${ }^{104}$

La jurisprudencia comunitaria exige el cumplimiento de determinados requisitos para que sea admisible la compensación, como que los parámetros para su cálculo estén establecidos previamente de forma objetiva, transparente, ${ }^{105}$ que la determinación de los costes del servicio universal no se haga "de manera global e imprecisa, sin efectuar un cálculo específico". ${ }^{106}$ No tendrán los efectos de ayuda de Estado si se han verificado todos los costes adicionales para prestar el apoyo. ${ }^{107}$

La garantía del servicio universal, tal como se entiende en la jurisprudencia de la UE es lo que justifica, por ejemplo, como interés público "garantizar la extensión y cobertura universal de los canales de televisión de ámbito estatal en las zonas dispersas y aisladas del territorio nacional a las que no alcanza el compromiso asumido por los concesionarios de televisión".108 Es la Administración quien fija el coste neto de las obligaciones del servicio universal. ${ }^{109}$

En esas misiones u obligaciones de servicio público, en la garantía en definitiva del "servicio universal", reside una diferencia fundamental de la regulación económica europea y americana. El interés público está

\footnotetext{
${ }^{104}$ Cfr. STJ de 24 de julio de 2003, asunto C-280/00 Atmark Trans GMBH. A "las subvenciones públicas que compensan los costes adicionales ocasionados por la ejecución de obligaciones de servicio público "no se aplica el artículo 73 del Tratado CE. Son la contrapartida de las actividades prestadas por ese concepto.

${ }^{105}$ Asunto Atmark, cit.

${ }^{106}$ Cfr. STJ de 6 de diciembre de 2001, asunto C-146/00.

107 MEILÁN GIL, J. L., Progreso... pp. 44-52 sobre el impacto del Derecho comunitario.

${ }_{108}$ ATS de 18 de diciembre de 2009 que deniega la suspensión solicitada por una empresa.

${ }^{109}$ STS de 24 de febrero de 2009 (RJ 1251). En ese caso por la Comisión Nacional de Telecomunicaciones.
} 
en el origen y desarrollo de las public utilities, ligado a las peculiaridades de las regulatory o independent Agencies. La diferencia fundamental proviene de las respectivas tradiciones: la regulation supone la intervención del government en actividades de titularidad privada, en tanto que en la versión europea implica intervención en actividades - servicios públicos — que eran de su titularidad. ${ }^{110}$

El Derecho administrativo permanece, usando la expresión de Otto Mayer en un contexto diferente, para la adjudicación de contratos realizados por empresas privadas en los sectores del agua, energía, transportes y telecomunicaciones en el ámbito del Derecho de la U.E. La "huida del Derecho administrativo" no se confirma en estas actividades que eran servicio público, en las que la titularidad correspondía a la Administración y la gestión al particular. ${ }^{111}$ En definitiva, a la Administración corresponde, dicho de una manera breve, la gestión de los intereses generales, que puede realizar de diferentes maneras.

\section{A modo de conclusiones}

Los derechos fundamentales son intereses generales permanentes. Otros intereses generales son variables de acuerdo con la alternancia democrática como concreción de los programas de los gobiernos en relación con la declaración de servicios esenciales y, en general, en desarrollo de los principios constitucionales rectores de la política social y económica y en ese sentido con posibilidad de ser invocados ante los Tribunales y aplicados por ellos en ocasiones como un principio general de Derecho.

El interés general como categoría jurídica ha dejado de ser una referencia genérica para el control de la potestad discrecional de la Administración, que se logra con el sometimiento de ella al Derecho (fin de la potestad, hechos, principios generales).

Los intereses generales, interpretados por los jueces, juegan directamente un papel en resoluciones de carácter provisional tendentes a no frustrar la decisión sobre la legalidad de la actuación.

Intereses generales e interés público son equivalentes. La utilización del primero en la Constitución respondió a la finalidad de evitar el equívoco del interés público como interés dominical de la Administración.

\footnotetext{
${ }^{110}$ Cfr. MEILÁN GIL, J. L., Una aproximación... La reforma sanitaria de la Administración Obama y la resistencia a ella contrasta con el servicio universal de la seguridad social europea.

111 Ley 48/1998 de 30 de abril, transposición de la Directiva 2004/17/CE.
} 
Esos intereses permanecen como obligación primaria a garantizar por la Administración, cualquiera que sea la participación de los particulares en su consecución.

La consecución del interés general requiere, en definitiva, una relación de Estado y sociedad que no se encuentre perturbada por el radicalismo de uno $u$ otro sentido. Sobre esa relación público-privada, pesan planteamientos ideológicos que no han de ignorarse. ${ }^{112}$ Es deseable una colaboración. ${ }^{113}$

A superar la contraposición dialéctica público-privado ayuda la consideración de intereses supraindividuales y sociales que procuran la realización del interés general sin necesidad de integrarse directa o indirectamente en la estructura orgánica de una Administración Pública. $Y$ es que, como vengo diciendo desde hace bastantes años, no todo interés público es interés de la Administración Pública. Existe interés público en entes que no forman parte de la Administración Pública, trátese de entes reconocidos constitucionalmente para la representación profesional o sindical o análogos o de organizaciones no gubernamentales y equivalentes para la promoción o defensa de asuntos que no responden al objetivo del lucro económico, sino a otros de carácter eminentemente colectivo o social. ${ }^{114}$

Es lo que corresponde a un Estado social y democrático de Derecho en el que la participación de los ciudadanos y el pluralismo suponen una relación esencial entre la sociedad y el Estado y la negación de una asunción monopolista y excluyente de los intereses generales por la Administración. En palabras del Tribunal Constitucional:115 "La configuración del Estado como social de Derecho viene así a culminar una evolución en la que la consecución de los fines de interés general no es absorbida por el Estado, sino que se armoniza en una acción mutua Estado-Sociedad".

Volvemos a la noción del bien común mencionada al principio "como idea integradora de intereses públicos y privados".116 Si el Estado

112 Cfr. MEILÁN GIL, J. L, Progreso... pp. 24-30. Sobre la dialéctica público privado. Cfr. LLANO, A. La nueva sensibilidad, Espasa Calpe, Madrid, 1988.

113 Un ejemplo actual es el contrato de colaboración entre el sector público y el sector privado (artículo 11 de la LCSP), de regulación discutible será construcción de grandes infraestructuras, que permite una financiación que la Administración no tiene disponible en el momento, con las correspondientes compensaciones.

114 Los intereses de grupo, como son los intereses profesionales, no se entienden como generales a efectos de legitimación para interponer recurso de casación en interés de la ley. STS de 17 de enero de 2008.

115 STC 18/1984 de 7 de febrero.

${ }^{116}$ SAINZ MORENO, F., “Reducción...”pp. 73. 
se desentendiese del interés general, no sería social, si lo monopolizase, no sería democrático.

General Interests and Public Interest From the Spanish Public Law Perspective

Abstract: The subject occupies a central place in Administrative Law and it is object of different understanding in the history of the various juridical systems, with new faces in each of its stages. Taking Spanish Law as a reference, a quick look at the current Constitution of 1978 allows to check several references to terms such as "general interest», "general interests», «national interest», «public interest». The purpose of this approach is to conduct a delimitation of these labile concepts using the technique of contrast, in the belief that the general interest or public interest can not be used as indiscriminate coverage of public power, that must consider them as acting criteria, guarantee them and serve them. Definitely the holder of power Government or Administration- should not take over the general interest or public interest, as if its domain, nor can they ignore them in favor of private interests, unlawfully abdicating its role.

Key words: General interests. Public interests. Spanish Public Law.

Informação bibliográfica deste texto, conforme a NBR 6023:2002 da Associação Brasileira de Normas Técnicas (ABNT):

MEILÁN GIL, José Luis. Intereses generales e interés público desde la perspectiva del derecho público español. A\&C - Revista de Direito Administrativo \& Constitucional, Belo Horizonte, ano 10, n. 40, p. 171-198, abr./jun. 2010.

Recebido em: 30.03 .10

Aprovado em: 25.05.10 